\title{
Hybrid cultivars of pear in subtropics regions: processing ability in the form of jelly
}

\author{
Paula Nogueira Curi ${ }^{1}$ Rayane Barcelos Bisi ${ }^{1}$ Derlyene Lucas Salgado ${ }^{2}$ \\ Caio Morais de Alcântara Barbosa ${ }^{1}$ Rafael Pio ${ }^{1 *}$ Vanessa Rios de Souza ${ }^{2}$
}

\author{
${ }^{1}$ Departamento de Agricultura, Universidade Federal de Lavras (UFLA), 37200-000, Lavras, MG, Brasil. E-mail: rafaelpio@dag.ufla.br. \\ ${ }^{*}$ Corresponding author. \\ ${ }^{2}$ Departamento de Ciência dos Alimentos, Universidade Federal de Lavras (UFLA), Lavras, MG, Brasil.
}

ABSTRACT: The aim of this study was to characterize five different hybrid cultivars pears ('Tenra', 'Centenária', 'Cascatence', 'Primorosa' and 'Seleta') deployed in subtropical regions of Brazil regarding its physicochemical characteristics, bioactive compounds and antioxidant activity, as well as to evaluate the influence of these cultivars on the characteristics physicochemical, rheological properties and sensory acceptance of the obtained jelly, for identifying varieties with higher potential for industrial use. Regardingthe bioactive compounds and antioxidant activity it was observed that 'Seleta' cultivar was characterized by a higher phenolic content (57.68mg GAEs 100g-1), higher antioxidant activity (13.56\% of DPPH sequestration and $1.25 \mu \mathrm{M}$ of trolox $\left.\mathrm{g}^{-1}\right)$ and higher content of vitamin C $\left(3.59 \mathrm{mg} 100 \mathrm{~g}^{-1}\right)$. As the acidity, it ranged from 4.09 to $5.81 \mathrm{~g}$ of malic acid $100 \mathrm{~g}^{-1}$ ('Tenra' and 'Seleta', respectively). Regarding color, the color parameter $L^{*}$ varied from 32.14 to 36.83 , a ranged from 2.87 to $5.20, b^{*}$ ranged from 16.57 to 20.42 , Chroma ranged from 16.67 to 21.02 and ${ }^{\circ} \mathrm{Hue}$ ranged from 74.94 to 80.18. Regarding the texture, the jellies produced from 'Centenária' and 'Tenra' were characterized by having the highest values of hardness (1.21 and $1.23 N$, respectively), gumminess ( 0.42 and 0.45 , respectively) and chewiness ( 0.40 and $0.45 N$, respectively). The jelly obtained from

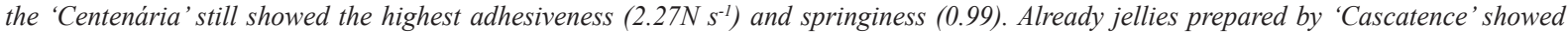
the highest cohesiveness values (0.68). The jellies prepared with different pear cultivars showed good sensory acceptance for all measured properties, with average scores ranging between the hedonic terms "liked slightly" to "liked very much". Cultivars of subtropical pear trees present different physicochemical characteristics, resulting in jellies with different physicochemical characteristics and rheological properties. Processing in the form of jelly is extremely viable due to the good acceptance by consumers of all formulations elaborated. Key words: Pyrus communis $x$ Pyrus pyrifolia, quality, sensory acceptance.

Cultivares de peras híbridas em regiões subtropicais: aptidão para processamento na forma de geleia

RESUMO: O objetivo deste estudo foi caracterizar cinco diferentes cultivares hibridas de peras ('Tenra', 'Centenária', 'Cascatence', 'Primorosa'e 'Seleta') implantadas em regiões subtropicais do Brasil quanto as caracteristicas fisico-química, compostos bioativos e atividade antioxidante, bem como avaliar a influência destas cultivares sobre as características físico-químicas, propriedades reológicas e aceitação sensorial da geleia obtida, para identificação de cultivares com maior potentcial para a utilização industrial. Com relação aos compostos bioativos e atividade antioxidante, pode-se observar que a cultivar 'Seleta' caracterizou-se pelo maior teor de fenólicos (57,68mg GAEs $\left.100 \mathrm{~g}^{-1}\right)$, maior atividade antioxidante (13,56\%

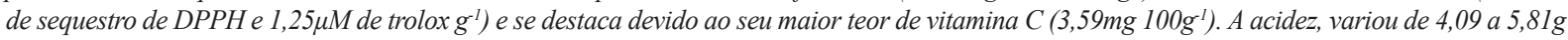
de ácido málico $100 \mathrm{~g}^{-1}$ ('Tenra'e 'Seleta', respectivamente). Em relação à cor, o parâmetro de cor $L^{*}$ variou de 32,14 a 36,83, a* variou de 2,87 a 5,20, $b^{*}$ variou de 16,67 a 20,42, Chroma variou de 16,57 a 21,02 e ${ }^{\circ}$ Hue variou de 74,94 a 80,18. Em relação à textura, as geleias produzidas a partir de 'Centenária'e 'Tenra' caracterizam-se por apresentar os maiores valores de dureza (1,21 e 1,23N, respectivamente), gomosidade (0,42 e $0,45 \mathrm{~N}$, respectivamente) e mastigabilidade $(0,40$ e 0,45, respectivamente). A geleia obtida da 'Centenária' ainda apresentava a maior adesividade $\left(2,27 \mathrm{~N} \mathrm{~s}^{-1}\right)$ e a elasticidade (0,99). Já as geleias preparadas com a 'Cascatence' apresentaram os maiores valores de coesividade (0,68). As geleias preparadas com diferentes cultivares de pera mostraram boa aceitação sensorial para todas as propriedades avaliadas, com notas médias variando entre os termos hedônicos "gostei ligeiramente" e "gostei muito". As cultivares de pereiras subtropicais apresentam características fisico-químicas diferentes, resultando em geleias com características fisico-químicas e propriedades reológicas distintas. O processamento sob a forma de geleia é extremamente viável devido à boa aceitação por parte dos consumidores de todas as formulações elaboradas.

Palavras-chave: Pyrus communis x Pyrus pyrifolia, qualidade, aceitação sensorial.

\section{INTRODUCTION}

Plants particularly horticulture section are raw material and used by people for food, either as edible products, or for culinary ingredients, for medicinal use or ornamental and aesthetic purposes. They are genetically very diverse group and play a major role in modern society end economy. Fruits and vegetables are an important component of traditional food, but are also central to healthy diets 
of modern urban population (PENONI et al., 2011; GUEDES et al., 2017).

The production of pears in Brazil is quite insignificant, being around 20 tons per year. Despite the pear is a temperate fruit, there are some cultivars that adapted well in subtropical regions with mild winter, such as hybrid cultivars from Pyrus communis x Pyrus pyrifolia (NOGUEIRA et al., 2016). The main hybrid cultivars exploited in tropical regions in South America are 'Tenra', 'Centenária', 'Cascatence', 'Primorosa' and 'Seleta', launched by the Agronomic Institute (IAC), Campinas/SP (BETTIOL NETO et al., 2014).

The increased consumption of pears is related mainly to the attractive and distinctive flavor of their fruits and their nutritional and functional characteristics. Pears are rich in bioactive compounds, such as phenolic antioxidants and providing a high amount of energy, vitamins, minerals and dietary fiber (SAEEDUDDIN et al., 2016).

In general the fruits are highly perishable and there are several problems related to their conservation which may restrict their consumption so one way to raise the consumption and one way of increasing the value of the final product is the formulation of processed foods, in the form of juices and jellies.

According to the resolution - CNNPA $n^{\circ}$. 12, 1978, fruit jelly is the product prepared with fruits or juices that can present whole fruits or pieces in various forms, such ingredients being mixed with sugars, with or without added water, pectin, acids and further ingredients allowed by such standards; such a mixture will be suitably processed to a suitable semi-solid consistency and finally packaged in a manner to ensure its perfect preservation. The jellies can be made with one or more species of fruit and are therefore designated as simple or mixed respectively. This product may be of the common or extra type according to the proportion of juice and sugar used. Most fruits can be processed into jelly, even those with low pectin and acid content. In that case, it's necessary to add these substances in processing. (MÉLO et al., 1999).

Due that, the objective of this study was to characterize the different hybrid cultivars pears deployed in subtropical regions of Brazil as the physicochemical characteristics, bioactive compounds and antioxidant activity, as well as to evaluate the influence of these cultivars on the characteristics physicochemical, rheological properties and sensory acceptance of the obtained jelly, for identifying varieties with higher potential for industrial use.

\section{MATERIALS AND METHODS}

The jellies were processed from five hybrid cultivars of pears ('Tenra', 'Centenária', 'Cascatence', 'Primorosa' and 'Seleta'). Fruits were harvested from the farm in subtropical region in Brazil, at their physiological maturity. In addition to the fruit, sucrose, high-methoxyl pectin and citric acid were used for the preparation ofjellies. Those fruits that had some mechanical or microbiological damage were discarded and the removal of leaves was done manually, after this procedure the fruits were washed with water. Pears were homogenized in a blender with the addition of $50 \%$ water and for obtaining the clarified juice this slurry was passed through a sieve. To elaborate the jellies it was used $65 \%$ of clarified pear juice, 35\% sugar, 1\% high methoxyl pectin and $0.5 \%$ citric acid. For the development of pear jelly the sugar was added and then the mixture was heated in an open pan. Pectin was added when it entered the boiling state. At the end of the process, when it presented soluble solids of $65^{\circ}$ Brix, the heating was stopped and citric acid was added.

The analyses were performed in the Postharvest Laboratory in three replications. To characterize the hybrid cultivars of pear, the analysis of length, diameter, unit weight, firmness, total soluble solids, total acidity, SS/total acidity (ratio), and color $\left(\mathrm{L}^{*}, \mathrm{a}^{*}, \mathrm{~b}^{*}\right.$, Chroma and $\left.{ }^{\circ} \mathrm{Hue}\right)$, were made in fresh fruits. Fruits of different pear cultivars were also further characterized as to phenolic compound content, vitamin $\mathrm{C}$ content and antioxidant activity (ABTS and DPPH method). Already in the jellies prepared from different hybrid cultivars pears, it was conducted the analysis of $\mathrm{pH}$, total acidity, color and texture profile analysis.

Length and diameter of fruit were measured with the aid of a digital caliper $150 \mathrm{~mm}$, and average fruit weight was determined by individual weighing of each fruit with the aid. For conducting fruit firmness, we measured the force required for a $3 \mathrm{~mm}$ probe coupled to a digital penetrometer, Instrutherm PTR-300, to overcome the resistance of the fruit pulp.

Total phenolic analysis was performed according to the Folin-Ciocalteu method with some modifications. Results were presented in $\mathrm{g}$ gallic acid equivalents (GAE). 100g-1. Antioxidant capacities of different pear cultivars were obtained by DPPH and ABTS methods. The antioxidant capacity was determined through the reduction of DPPH (2,2-diphenyl-1-picrylhydrazyl) by the antioxidant present in the sample. Results are expressed as micromoles of Trolox equivalents 
(TEs) per gram of fresh weight ( $\mu$ mol of TEs $\mathrm{g}^{-1}$ of f.w.). Antioxidant activity by the ABTS method. Results are expressed as micromoles of Trolox equivalents (TEs) per gram of fresh weight ( $\mu$ mol of TEs $\mathrm{g}^{-1}$ of f.w.). Vitamin $\mathrm{C}$ analysis was performed though the colorimetric method with 2,4-dinitrophenylhydrazine (2,4-DNPH).

Texture profile analyses (TPA) of the jellies were made in penetration mode under the conditions described by SOUZA et al. (2014a). The jelly samples were compressed by $30 \%$. Parameters analyzed were hardness, adhesiveness, springiness, cohesiveness, gumminess and chewiness.

Sensory analysis of different samples was obtained in the Sensory Analysis Laboratory.
Acceptance testing was obtained with 90 people, including 50 women and 40 men, where the evaluated characteristics were color, taste, texture and overall liking, by using a hedonic scale of 9 points $(1=$ extremely dislike, $9=$ extremely like).

Univariate statistical analysis (ANOVA) and Tukey test were used to check for significant differences between the samples at a significance level of $5 \%(\mathrm{P} \leq 0.05)$.

\section{RESULTS AND DISCUSSION}

Regarding the size and weight parameters of the different pear cultivars (Table 1), it can been seen that the 'Centenária' presented larger dimension,

Table 1 - Average length (AL), average diameter (AD), unit weight (UW), total soluble solids (SS), total acidity (TA), solids / acidity (ratio), firmness (Firm.), color $\left(\mathrm{L}^{*}, \mathrm{a}^{*}, \mathrm{~b}^{*}\right.$, Chroma and $\left.{ }^{\circ} \mathrm{Hue}\right)$, the total phenolics, antioxidant capacity (DPPH and ABTS) and vitamin $\mathrm{C}$ in five pear tree cultivars. UFLA, Lavras - MG, 2017.

\begin{tabular}{|c|c|c|c|c|}
\hline Cultivars & $\mathrm{AL}(\mathrm{mm})$ & $\mathrm{AD}(\mathrm{mm})$ & UW (g) & SS $\left({ }^{\circ}\right.$ Brix $)$ \\
\hline ‘Tenra' & $73.93 b c$ & $79.47 \mathrm{a}$ & $236.66 a$ & $11.70 \mathrm{ab}$ \\
\hline 'Centenária' & $86.04 \mathrm{a}$ & $71.41 \mathrm{a}$ & $211.66 \mathrm{a}$ & $11.53 \mathrm{ab}$ \\
\hline 'Cascatence' & $83.21 \mathrm{ab}$ & $66.97 \mathrm{a}$ & $160.66 \mathrm{a}$ & $10.30 \mathrm{~b}$ \\
\hline 'Primorosa' & $83.28 \mathrm{ab}$ & $70.01 \mathrm{a}$ & $196.66 \mathrm{a}$ & $10.60 \mathrm{ab}$ \\
\hline 'Seleta' & $70.28 \mathrm{c}$ & $69.76 \mathrm{a}$ & $166.66 \mathrm{a}$ & $12.26 \mathrm{a}$ \\
\hline $\mathrm{CV}(\%)$ & 4.88 & 7.86 & 21.29 & 3.86 \\
\hline Cultivars & TA (\%) & Ratio & Firm. & $\mathrm{L}^{*}$ \\
\hline 'Tenra' & $6.73 a$ & $1.73 \mathrm{c}$ & $18.66 b c$ & $67.30 \mathrm{a}$ \\
\hline 'Centenária' & $1.93 \mathrm{~d}$ & $6.21 \mathrm{a}$ & $25.70 \mathrm{~b}$ & $66.66 \mathrm{a}$ \\
\hline 'Cascatence' & $3.37 \mathrm{ab}$ & $3.05 \mathrm{bc}$ & $11.45 \mathrm{c}$ & $69.61 \mathrm{a}$ \\
\hline 'Primorosa' & $2.36 \mathrm{~cd}$ & $4.54 \mathrm{ab}$ & $49.70 \mathrm{a}$ & $62.17 b$ \\
\hline 'Seleta' & $3.28 \mathrm{bc}$ & $3.76 \mathrm{bc}$ & $8.78 \mathrm{c}$ & $67.09 \mathrm{a}$ \\
\hline $\mathrm{CV}(\%)$ & 6.51 & 5.11 & 17.24 & 1.92 \\
\hline Cultivars & $a^{*}$ & $b^{*}$ & Chroma & ${ }^{\circ}$ Hue \\
\hline 'Tenra' & $1.14 \mathrm{ab}$ & $16.58 \mathrm{~b}$ & $16.63 b$ & $90.45 a$ \\
\hline 'Centenária' & $1.85 \mathrm{ab}$ & $20.08 \mathrm{ab}$ & $20.18 \mathrm{ab}$ & $91.79 a$ \\
\hline 'Cascatence' & $0.53 b$ & $22.90 \mathrm{~b}$ & $22.92 \mathrm{a}$ & $91.18 \mathrm{a}$ \\
\hline 'Primorosa' & $1.88 \mathrm{ab}$ & $16.22 \mathrm{a}$ & $16.33 b$ & $96.70 \mathrm{a}$ \\
\hline 'Seleta' & $2.67 \mathrm{a}$ & $21.33 \mathrm{a}$ & $21.50 \mathrm{a}$ & $97.24 \mathrm{a}$ \\
\hline CV(\%) & 37.04 & 7.92 & 7.82 & 5.00 \\
\hline Cultivars & Total phenolics & Antioxidant capacity - DPPH & Antioxidant capacity - ABTS & Vitamin C \\
\hline 'Tenra' & $43.93 b$ & $10.89 \mathrm{~b}$ & $1.41 \mathrm{c}$ & $2.95 b$ \\
\hline 'Centenária’ & $21.28 \mathrm{c}$ & $2.53 \mathrm{c}$ & $2.44 \mathrm{ab}$ & $2.79 b$ \\
\hline 'Cascatence' & $52.79 \mathrm{ab}$ & $10.96 \mathrm{~b}$ & $1.65 \mathrm{bc}$ & $2.38 \mathrm{c}$ \\
\hline 'Primorosa' & $44.73 b$ & $3.78 \mathrm{c}$ & $3.18 \mathrm{a}$ & $1.32 \mathrm{~d}$ \\
\hline 'Seleta' & $57.68 \mathrm{a}$ & $13.56 \mathrm{a}$ & $1.25 \mathrm{c}$ & $3.59 \mathrm{a}$ \\
\hline $\mathrm{CV}(\%)$ & 7.90 & 7.99 & 14.23 & 4.98 \\
\hline
\end{tabular}

"Mean values with common letters in the same column indicate that there is no significant difference among samples $(\mathrm{P}<0.05)$ from Tukey's mean test. ${ }^{* *}$ Total acidity: g malic acid $100 \mathrm{~g}^{-1}$ f.w; Total phenolics (mg GAEs $100 \mathrm{~g}^{-1}$ f.w.); Antioxidant capacity - DPPH (\% de sequestration); Antioxidant capacity - ABTS ( $\mu \mathrm{M}$ de trolox $\mathrm{g}^{-1}$ of fresh fruit); vitamin $\mathrm{C}$ ( $\mathrm{mg}^{100 \mathrm{~g}^{-1}}$ f.w.). ${ }^{* * *} \mathrm{Abbreviations:} \mathrm{DPPH:} 2-$ diphenyl-1-picryhydrazyl radical scavenging activity; GAE: gallic acid equivalent. 
with $86.04 \mathrm{~mm}$ in average length, but in the case of the average diameter and unit mass there was no significant difference between cultivars. Average diameter ranged from $66.97 \mathrm{~mm}$ to $79.47 \mathrm{~mm}$ and the weight ranged from 160.66 to 236.66 grams.

The soluble solids content ranged from 10.30 to $12.26^{\circ}$ Brix, acidity ranged from 1.93 to $6.73 \mathrm{~g}$ of malic acid. $100 \mathrm{~g}^{-1}$ and the ratio ranged from 1.73 to 6.73 . The 'Seleta' highlighted by having the highest content of soluble solids. Already 'Centenária' presented the highest ratio, representing the cultivar with the best balance between soluble solids and acidity. These parameters often indicated the target fruit, once identified which are recommended for the consumption of fresh fruit or processing. The higher the content of sugars and organic acids, the higher the content of soluble solids. Generally, consumers opted for more sweet fruit, so the fruit with the most widely accepted are those with high soluble solids content and high content of total sugars. However, it is through the ratio of TSS/TTA (ratio), which assesses whether the fruit has a striking and distinctive flavor. This relationship (SS/AT), influenced by climatic conditions, especially by luminosity and temperature, is considered appropriate for determining fruit quality (MARO et al., 2013).

In general, the values reported for soluble solids this study are higher than those reported by BETTIOL NETO et al. (2014), where the value was in the range $9.00^{\circ}$ Brix in those cultivars. All cultivars showed high acidity and then indicated to process through the preparation of jams, jellies and jams, which has gel formation, increased acidity is more significant.

Regarding the fruit firmness, the range of variation was from 8.78 ('Seleta') to $49.70 \mathrm{~N}$ ('Primorosa') (Table 1). These results are in accordance with BETTIOL NETO et al. (2014), that studying different cultivars, verified that the 'Primorosa' was the firmest, presenting greater resistance of the pulp to penetration. Importantly, the difference in the firmness of the cultivars may be due to differences in the fruit maturation stage and not only differences due to cultivar because; although, great care has been taken, we cannot guarantee that all the fruits of all cultivars were collected exactly at the same ripening stage.

In relation to the fruit color, the color parameter $\mathrm{L}^{*}$ ranged from 62.17 to $69.61, \mathrm{a}^{*}$ from 0.53 to 2.67 and $b^{*}$ from 16.22 to 22.90 (Table 1 ). The 'Primorosa' cultivar highlighted due to the lower value of $L^{*}$ (62.17), been characterized as the darker cultivar. Already 'Cascatence' presented the lowest values of $a^{*}$ and $b^{*}$ color parameters, being greener cultivars. In relation to the Chroma the 'Cascatence' and 'Seleta cultivars showed the highest values, resulting in greater color intensity and for the hue angle, it was reported that all cultivars are yellowish, as expected.

Regarding to the bioactive compounds and antioxidant activity (Table 1), one can be seen that the 'Seleta' cultivar characterized by having the highest phenolic content (57.68mg GAEs $100 \mathrm{~g}^{-1}$ ), higher antioxidant activity (13.56\% of DPPH sequestration and $1.2 \mu \mathrm{M}$ of trolox $\left.\mathrm{g}^{-1}\right)$ and still stands out due to its higher content of vitamin $\mathrm{C}\left(3.59 \mathrm{mg} 100 \mathrm{~g}^{-1}\right)$.

Tables 2 and 3, respectively, showed the average values of the physicochemical properties and textures of different jellies prepared with pear cultivars. Through the analysis of variance a significant difference was reported for all parameters, except to total acidity.

The $\mathrm{pH}$ values ranged from 2.99 to 3.05 ('Centenária' and 'Cascatence' respectively). As the acidity, it ranged from 4.09 to $5.81 \mathrm{~g}$ of malic acid $100 \mathrm{~g}^{-1}$ ('Tenra' and 'Seleta', respectively) (Table 2). After processing the jellies presented $\mathrm{pH}$ and acidity relatively similar to each other. Regarding color, the color parameter $\mathrm{L}^{*}$ varied from 32.14 to 36.83 , a* ranged from 2.87 to $5.20, \mathrm{~b}^{*}$ ranged from 16.57 to 20.42, Chroma ranged from 16.67 to 21.02 and ${ }^{\circ}$ Hue ranged from 74.94 to 80.18 (Table 2). According to table 2, regarding the color parameter $a^{*}$, jelly obtained by 'Tenra', 'Centenária' and 'Cascatense' presented a more reddish tone and in relation to the colors parameters $\mathrm{L}^{*}$ and $\mathrm{b}^{*}$, 'Centenária' stood out as the clearer jelly, together with the 'Cascatense' as the most yellowish jelly.

Regarding texture, it is perceived by the average table (Table 3) that jellies produced from 'Centenária' and 'Tenra' are characterized by present the highest values of hardness (1.21 and 1.23, respectively), gumminess ( 0.42 and 0.45 , respectively) and chewiness ( 0.40 and 0.45 , respectively). Jelly obtained from the 'Centenária' still showed the highest adhesiveness (2.27) and springiness (0.99). Already jellies prepared by cultivating 'Cascatence' showed the highest cohesiveness values (0.68). Hardness reflects the force necessary to obtain a certain deflection, gumminess reflects the force necessary to masticate a semi-solid food and chewiness reflects the power necessary to simulate chewing a semisolid sample in a constant state of swallowing. In this way, the jellies obtained by 'Tenra' and 'Centenária' characterized by being more rigid and firm. As the adhesiveness reflects the force to simulate the work necessary to overcome the attractive forces between 
Table 2 - pH, total acidity (TA) and color $\left(\mathrm{L}^{*}, \mathrm{a}^{*}, \mathrm{~b}^{*}\right.$, Chroma and ${ }^{\circ}$ hue $)$ in five pear jellies obtained by different cultivars. UFLA, Lavras MG, 2017.

\begin{tabular}{|c|c|c|c|c|c|c|c|}
\hline Cultivars & $\mathrm{pH}$ & TA & $\mathrm{L}^{*}$ & $a^{*}$ & $b^{*}$ & Chroma & ${ }^{\circ} \mathrm{Hue}$ \\
\hline 'Tenra' & $3.03 \mathrm{ab}$ & $4.09 \mathrm{a}$ & $34.53 \mathrm{ab}$ & $4.56 \mathrm{a}$ & $18.11 \mathrm{ab}$ & $18.67 \mathrm{ab}$ & $75.87 b$ \\
\hline 'Centenária' & $2.99 \mathrm{c}$ & $4.55 \mathrm{a}$ & $36.83 a$ & $5.20 \mathrm{a}$ & $19.38 \mathrm{a}$ & $20.07 \mathrm{a}$ & $74.94 b$ \\
\hline 'Cascatence' & $3.05 \mathrm{a}$ & $4.20 \mathrm{a}$ & $32.14 b$ & $4.98 \mathrm{a}$ & $20.42 \mathrm{a}$ & $21.02 \mathrm{a}$ & $76.30 \mathrm{~b}$ \\
\hline 'Primorosa' & $3.01 b c$ & $4.43 a$ & $33.41 \mathrm{~b}$ & $2.87 \mathrm{~b}$ & $16.57 \mathrm{~b}$ & $16.82 \mathrm{~b}$ & $80.18 \mathrm{a}$ \\
\hline 'Seleta' & $3.04 \mathrm{ab}$ & $5.81 \mathrm{a}$ & $32.75 b$ & $3.42 \mathrm{~b}$ & $18.37 \mathrm{ab}$ & $18.69 \mathrm{ab}$ & $79.43 \mathrm{a}$ \\
\hline CV(\%) & 0.40 & 24.99 & 2.96 & 8.56 & 5.03 & 5.13 & 0.81 \\
\hline
\end{tabular}

"Mean values with common letters in the same column indicate that there is no significant difference between samples (P $\leq 0.05)$ by Tukey's mean test. ${ }^{* *}$ Total acidity: g malic $100 \mathrm{~g}^{-1}$ f.w.

the food surface and the surface in contact with it and springiness measures the rate at which the deformed material returns to its original state after removal of the force, the jelly obtained from the 'Centenária' still characterized by being the more adhesive and elastic jelly. Since, cohesiveness reflects as a material can be stretched without breaking irreversibly.

There are some reasons that explain the texture variation between jellies prepared from different cultivars; among them, sugar, $\mathrm{pH}$, acidity and soluble pectin content are the main factors that can influence the gelling and the product texture (SOUZA et al., 2014b).

For consistency and overall liking attributes it was confirmed by analysis of variance a significant difference between the different formulations of pear jelly ( $\mathrm{P} \leq 0.05)$. Table 4 shows the average values and significant test for the evaluated sensorial characteristics.
It can been seen that the jellies prepared with different pear cultivars showed good sensory acceptance for all measured properties, with average scores ranging between the hedonic terms "liked slightly" to "liked very much" (Table 4). As for color and taste attribute, there were no significant differences between the different samples, with all samples having average scores higher than 7. Color is of fundamental importance, since it is linked to attractiveness to the consumer (MATSUURA et al., 2002). Pear jams made with the 'Primorosa' showed greater acceptance in relation to consistency. Conversely, the jellies elaborated by the 'Centenária' were less accepted. The consistency of the jelly is influenced by the acidity and the concentrations of pectin (PEREIRA et al., 2011). Regarding overall liking, the consumers demonstrated greater acceptability for the jelly made with the 'Cascatence'. Jelly produced with the cultivar 'Centenária' was the least accepted.

Table 3 - Hardness (Hard), adhesiveness (Adhe N/s), springiness (Sprin), cohesiveness (Cohe), gumminess (Gummi N) and chewiness (Chew) in five pear jellies obtained by different cultivars. UFLA, Lavras - MG, 2017.

\begin{tabular}{lcccccc}
\hline Cultivars & Hard & Adhe & Spr & Cohe & Gum \\
\hline 'Tenra' & $1.23 \mathrm{a}$ & $1.56 \mathrm{~b}$ & $0.96 \mathrm{bc}$ & $0.34 \mathrm{~b}$ & $0.42 \mathrm{a}$ & $0.40 \mathrm{a}$ \\
'Centenária' & $1.21 \mathrm{a}$ & $2.27 \mathrm{a}$ & $0.99 \mathrm{a}$ & $0.37 \mathrm{~b}$ & $0.45 \mathrm{a}$ & $0.45 \mathrm{a}$ \\
'Cascatence' & $0.04 \mathrm{~d}$ & $0.29 \mathrm{c}$ & $0.98 \mathrm{ab}$ & $0.68 \mathrm{a}$ & $0.03 \mathrm{c}$ & $0.03 \mathrm{c}$ \\
'Primorosa' & $0.45 \mathrm{c}$ & $1.51 \mathrm{~b}$ & $0.95 \mathrm{c}$ & $0.41 \mathrm{~b}$ & $0.18 \mathrm{~b}$ & $0.17 \mathrm{~b}$ \\
'Seleta' & $0.71 \mathrm{~b}$ & $1.36 \mathrm{~b}$ & $0.98 \mathrm{ab}$ & $0.37 \mathrm{~b}$ & $0.26 \mathrm{~b}$ \\
CV $(\%)$ & 8.07 & 38.10 & 1.20 & 7.72 & 12.10 \\
\hline
\end{tabular}

"Mean values with common letters in the same column indicate that there is no significant difference between samples (P $\leq 0.05)$ by Tukey's mean test. 
Table 4 - Sensorial attributes of color, taste, consistency and overall liking in five pear jellies obtained by different cultivars. UFLA, Lavras - MG, 2017.

\begin{tabular}{lcccc}
\hline Cultivars & Color & Taste & \multicolumn{2}{c}{ Consistency } \\
\hline 'Tenra' & $7.19 \mathrm{a}$ & $7.20 \mathrm{a}$ & $5.94 \mathrm{bc}$ & $6.56 \mathrm{bc}$ \\
'Centenária' & $7.01 \mathrm{a}$ & $6.72 \mathrm{a}$ & $5.14 \mathrm{c}$ & $6.13 \mathrm{c}$ \\
'Cascatence' & $7.19 \mathrm{a}$ & $7.24 \mathrm{a}$ & $6.74 \mathrm{ab}$ & $6.18 \mathrm{a}$ \\
'Primorosa' & $7.07 \mathrm{a}$ & $7.15 \mathrm{a}$ & $6.89 \mathrm{ab}$ & $6.98 \mathrm{ab}$ \\
'Seleta' & $7.01 \mathrm{a}$ & $7.07 \mathrm{a}$ & $6.54 \mathrm{ab}$ & 17.53 \\
$\mathrm{CV}(\%)$ & 13.18 & 16.96 & 25.20 & \\
\hline
\end{tabular}

${ }^{*}$ Mean values with common letters in the same column indicate that there is no significant difference among samples $(\mathrm{P} \leq 0.05)$ from Tukey's mean test.

The average table (Table 4) it can be seen that the 'Tenra' and 'Centenária' give rise jellies with lower acceptance for consistency and overall impression attributes. It can also assume that what affected the overall impression of these jellies were the lowest notes for its consistency, which was among the hedonic terms "not liked/not disliked" and "liked slightly". However, as the gelatinous consistency can be easily handled hitting the way in which will be processed, all pear cultivars have enormous potential to be processed in form of jelly.

Higher productivity was reported in the 'Tenra' and lower production by plants was reported in 'Centenária' and 'Seleta' (BETTIOL NETO et al., 2014). Thus, there is an indication that the 'Tenra' would be a good option of cultivar to prepare jellies.

\section{CONCLUSION}

The cultivars of subtropical pear trees presented different physicochemical characteristics, resulting in jellies with different physicochemical characteristics and rheological properties. The processing in the form of jelly is viable due to the good acceptance by the consumers of all formulations elaborated.

\section{REFERENCES}

BETTIOL NETO, J.E. et al. Production and postharvest quality of pear tree cultivars in subtropical conditions at eastern of São Paulo state, Brazil. Ciência Rural, v.44, p.1740-1746, 2014. Available from: <http://www.scielo.br/scielo.php?script=sci_ar ttext\&pid $=$ S0103-84782014001001740>. Accessed: Sept. 30, 2016. doi: 10.1590/0103-8478cr20131574.

GUEDES, M.N.S. et al. Antioxidant activity and total phenol content of blackberries cultivated in a highland tropical climate. Acta Scientiarum. Agronomy, v.39, p.43-48, 2017. Available from: <http://periodicos.uem.br/ojs/index.php/ActaSciAgron/ article/view/28413>. Accessed: Sept. 30, 2016. doi: 10.4025/ actasciagron.v39i1.28413.

MARO, L.A.C. et al. Bioactive compounds, antioxidant activity and mineral composition of fruits of raspberry cultivars grown in subtropical areas in Brazil. Fruits, v.68, p.209-217, 2013. Available from: <http://www.pubhort.org/fruits/2013/03/ fruits130068.htm>. Accessed: May 16, 2017. doi: 10.1051/ fruits/2013068.

MATSUURA, F.C.A.U. et al. Qualidade sensorial de frutos de híbridos de bananeira cultivar 'Pacovan'. Revista Brasileira de Fruticultura, v.24, p.263-266, 2002. Available from: $<$ http://www.scielo.br/scielo.php?script=sci_arttext\&pid $=$ S0100-29452002000100058 $>$. Accessed: May 16, 2017. doi: 10.1590/S0100-29452002000100058.

MÉLO, E.A. et al. Formulação e avaliação físico-química e sensorial de geleia mista de pitanga (Eugenia uniflora L.) e acerola (Malpighia sp). Boletim Centro de Pesquisa de Processamento de alimentos, v.17, p.33-44, 1999. Available from: <http://revistas.ufpr.br/alimentos/article/view/13799>. Accessed: May 10, 2017. doi: 10.5380/cep.v17i1.13799.

NOGUEIRA, P.V.et al. Establishment of growth medium and quantification of pollen grains and germination of pear tree cultivars. Revista Ciência Agronômica, v.47, p.380-386, 2016. Available from: <http://www.scielo.br/scielo.php?script=sci ar ttext\&pid=S1806-66902016000200380>. Accessed: Oct. 10, 2016. doi: 10.5935/1806-6690.20160045.

PENONI, E.S. et al. Analysis of fruits and nuts of macadamia walnut cultivars. Ciência Rural, v.41, p.2080-2083, 2011.<http:// www.scielo.br/scielo.php?script $=$ sci_arttext\&pid $=$ S010384782011001200007\&lng=pt\&tlng=pt $>$. Accessed: Oct. 10, 2016. doi: 10.1590/S0103-84782011001200007.

PEREIRA, G.G. et al. Sensory evaluation of japanese quince jam with different concentrations of total soluble solids. Brazilian Journal of Food Technology, v.14, p.226-231, 2011. Available from: <http://www.scielo.br/pdf/bjft/v14n3/07.pdf>. Accessed: May 09, 2017. doi: 10.4260/BJFT2011140300027.

SAEEDUDDIN, M. et al. Physicochemical parameters, bioactive compounds and microbial quality of sonicated pear juice. 
International Journal of Food Science and Technology, v.51, p. 1552-1559, 2016. Available from: <http://onlinelibrary.wiley. com/doi/10.1111/ijfs.13124/abstract>. Accessed: Oct. 10, 2016 doi: $10.1111 /$ ijfs. 13124 .

SOUZA, V.R. et al. Evaluation of the jelly processing potential of raspberries adapted in Brazil. Journal of Food Science, v.79, p.407-412, 2014a. Available from: < http://www.ncbi.nlm. nih.gov/pubmed/24467459>. Accessed: Oct. 20, 2016. doi: 10.1111/1750-3841.12354

SOUZA, V.R. et al. Analysis of the subtropical blackberry cultivar potential in jelly processing. Journal of Food Science, v.79, p.1776-1781, 2014b. Available from: <http://www.ncbi. nlm.nih.gov/pubmed/25154800>. Accessed: Oct. 20, 2016. doi: 10.1111/1750-3841.12565. 